Tidsskrift for arbejdsliv nr. 4, 1999, s. 85-101.

Bente Elkjoer

\title{
Det er længe siden, at nogen har talt om den lærende organisation
}

I artiklen fortæller jeg historien om en offentlig dansk virksomhed, der ville være en lærende organisation. Virksomheden er imidlertid ikke kendt som en lærende organisation i dag, selvom det ikke skortede på den gode vilje og opbakning, da den nye organisation blev lanceret i midten af 1990'erne. I artiklen foreslår jeg, at årsagen til den lærende organisations korte liv skal findes i den pressede situation, organisationen dengang befandt sig i. En trussel om at privatisere virksomheden havde medført, at man tankte en del i effektiviserings- og legitimeringstiltag. Jeg viser også, at selve metoden til at gennemføre den lærende organisation - ved at sende alle medarbejdere på kursus - ikke automatisk fører til ændring af en virksomhed. Organisationsændringer er ikke en naturlig følge af de personrettede læreprocesser, kursusundervisning repræsenterer. Det er desuden vanskeligt at æendre individer, hvis der samtidig indføres nye kontrolforanstaltninger over for medarbejderne, og at der i øvrigt ikke sker nogen ændringer af organisationens arbejde.

\section{Indledning}

Det følgende er en historie om indførelsen af den lærende organisation i en dansk offentlig administration - jeg kalder den "Offad". Det er historien om et projekt, der var båret af en god idé - forestillingen om en levende og dynamisk organisation, en lærende organisation - og en fremsynet og moderne ledelse. Historien indeholder tillige positive og interesserede medarbejdere - og der var tilmed økonomiske midler at gøre godt med. Hvorfor er denne offentlige virksomhed så ikke i dag kendt som en lærende organisation?

I det følgende viser jeg, at årsagen hertil var, at den lærende organisation i Offad blev indført i en offentlig virksomhed, der i den borgerlige regeringstid havde været tæt på at blive privatiseret. Det havde fort til en række aktiviteter, der alle havde til formål at effektivisere arbejdsprocesserne og dermed legitimere Offad's status som offentlig virksomhed. Det betød, at indførelsen af den lærende organisation fandt sted i et organisatorisk univers præget af rationalisering. Det viste sig i den måde, hvorpå den lærende organisation blev gennemført i Offad, nemlig ved at sende alle medarbejdere på et nøje tilrettelagt kursus, der skulle fuldføres inden for en given tid. Følgen var, at den lærende organisation i Offad blev præget af en dobbelthed mellem, på den ene side, rationalisering af arbejdsprocesserne i virksomheden og, på 
den anden side, udvikling af medarbejderne på et kursus. Det er et velkendt middel at sende medarbejdere på kursus for at ændre organisationer, men organisationer forandres ikke automatisk gennem personrettet kursusundervisning.

Man skal finde baggrunden for dobbeltheden mellem en rationaliseringslogik rettet mod arbejdsprocesserne og et lærings- og udviklingsfokus på medarbejderne i den teori om den lærende organisation, der blev fulgt i Offad. Det uddyber jeg i det følgende afsnit om Offad og dens kurs mod en lærende organisation. Mit fokus på Offad's indførelse af den lærende organisation var rettet mod at forstå, hvad det var medarbejderne skulle lære på et kursus for at blive medlemmer af en lærende organisation. Det er baggrunden for at lade empiri indsamlingen og -bearbejdningen styres af læringsteoretiske overvejelser. I litteraturen om organisatorisk læring - og især i litteraturen om den lærende organisation - kan man finde argumenter for, at den lærende organisation skabes gennem udvikling af individer. Det kalder jeg i det følgende et "kognitivt" perspektiv på læring. Der findes imidlertid også argumenter imod at anlægge denne læringsteori på organisatorisk læring og den lærende organisation. Det er baggrunden for at introducere et såkaldt "socialt-kulturelt" perspektiv på læring. Det er spændingen mellem de to læringsteoretiske perspektiver, jeg anvender til at disponere analysen, der udgør det tredje og sidste afsnit i artiklen.

\section{Offad - med kurs mod den lærende organisation}

Offad er en offentlig institution inden for det sociale område. Organisationens primære arbejdsopgave er at behandle sager om enkeltpersoners eventuelle krav på økonomisk støtte. I midten af 1990'erne var der lidt under 300 ansatte, hvoraf langt hovedparten var AC'ere (hovedsageligt jurister) og kontormedarbejdere. Offad var organiseret som en traditionel hierarkisk offentlig institution med en ledelse bestående af en direktør og en vicedirektør foruden et antal kontorer med hver sin kontorchef. Foruden kontorerne for behandling af enkeltsager var der et par kontorer, hvor der blev udført såkaldt generel sagsbehandling samt en edb afdeling. Generel sagsbehandling var fortolkninger af lovstof, forespørgsler fra offentligheden og ministeren, personaleforhold, oversættelse samt udvikling af edb systemer.

Privatiseringstruslen havde i Offad ført til indførelse af en teknologi, der havde gjort en del af kontorpersonalet overflødigt. De var dog ikke blevet fyret, men i stedet tilbudt et kursus og deltagelse i en tutorordning, hvor hver enkelt kontormedarbejder var blevet parret med en akademisk medarbejder (AC'er). Formålet med tutorordningen var, at AC'eren skulle oplære kontormedarbejderen til at tage mere aktiv del i selve sagsbehandlingen af enkeltsager og dermed på sigt frigøre AC'erne til andre opgaver. I bestræbelserne på at effektivisere sagsbehandlingen og samtidig højne kvaliteten heraf tog Offad's ledelse senere initiativ til at gennemføre et Total Quality Management (TQM) projekt assisteret af et konsulentfirma.

Da den lærende organisation blev lanceret i Offad, betød det, at også AC'erne måtte igennem et længere kursusforløb. Formålet med at udvikle en lærende organisation i Offad var at give alle et "kompetencemæssigt løft", så de kunne udføre opgaver på et tilsvarende højere niveau. AC'erne skulle i den lærende organisation påtage sig opgaver rettet mod omverdenen i stedet for udelukkende at beskæftige sig med behandling af enkeltsager og desuden tage mere aktivt del i organisationsudviklingen. AC'erne skulle tillige påtage sig ansvaret for at kvalificere 
kontormedarbejderne til at udføre sagsbehandling, de skulle holde foredrag internt i organisation og for eksterne rekvirenter samt deltage i plejen af Offad's internationale kontakter.

Det var TQM-konsulenterne, der havde inspireret Offad's ledelse til at udvide TQM projektet til også at omfatte den lærende organisation. Derfor var det i konsulentfirmaets opfattelse af en lærende organisation, udviklingen af den lærende organisation i Offad spejlede sig.

Konsulenterne definerede en lærende organisation som "en organisation, der har gjort det til sit væsentligste kulturtræk at lære af erfaring" (van Hauen, Strandgaard \& Kastberg 1995, 39). De anviste desuden en metode for at udvikle en lærende organisation, der netop fordrede, at alle ansatte skulle deltage i et kursus. Det var et kursus i "personlig kvalitet", hvis formål var "at give den enkelte mulighed for at opleve sine egne evner til at lære nyt, styrke den enkeltes selvværd og udfordre den enkeltes antagelser" (op. cit.). Et kursus som dette ville bidrage til at udvide den enkeltes læringskompetence, og altså, ifølge konsulenterne, føre til en lærende organisation.

Kursusdeltagelse som en metode til at udvikle organisationer var et kendt middel i Offad. Det var den metode, ledelsen i Offad selv havde anvist til at omstille kontorpersonalet til at udføre sagsbehandling. Indholdet i AC'ernes kursus var forskelligt fra kontormedarbejdernes, men selve organiseringen af kurset var lig kontormedarbejdernes. Det var tvungent for AC'erne at deltage $\mathrm{i}$ kurset, og indholdet var det samme for alle uanset deres konkrete arbejde i Offad. AC'ernes kursus bestod af 5 moduler og varede 13 dage og ind imellem aftener, eftersom en del af kurset fandt sted i internat. Kurset forløb over en periode på ca. 2 måneder. Der var desuden sat tid af til at lave problemorienteret projektarbejde, i alt 4,5 dage, hvilket et fătal dog nøjedes med. Projektarbejdet blev udført i grupper à 4-7 deltagere og handlede om specifikke emner, som ledelsen havde godkendt som relevante. Eksempler på projekttitler var: "Bedre kontakt til klienter", "Fremtiden for AC'erne i Offad" og "Tutor - tanker og ideer om tutor-arrangementet". Offad havde i alt afsat et år til at føre alle AC'erne gennem deres kursus.

Titlerne på modulerne i AC'ernes kursus var følgende: "Total kvalitet og personlig kvalitet"; "Organisations- og ledelsesteori"; "Præsentations- og forhandlingsteknik" og "Skriftlig kommunikation". Heri var indeholdt to jurafaglige dage om henholdsvis EU-ret og Forvaltningsloven. I det sidste modul, afslutningsmodulet, fremlagde kursisterne deres projekter, hvorpå repræsentanter fra ledelsen kommenterede dem. Idéen med projektarbejdet var, at AC'erne skulle lære at samarbejde i grupper og anvende nogle af de færdigheder, de havde lært i de andre moduler. De skulle ligeledes anvende præsentationsteknik, når de skulle fremlægge projekterne.

TQM-konsulenterne i Offad anså TQM og den lærende organisation for at være to sider af samme sag. De betragtede TQM som en metode til at effektivisere sagsbehandlingen i Offad, og den lærende organisation var med sit fokus på udvikling af medarbejdere, ifølge konsulenterne, en naturlig pendant til TQM. Medarbejderne i en lærende organisation skulle således lære at tænke og handle anderledes i forhold til deres arbejde og organisationen som helhed. De skulle se sig selv som medspillere frem for modparter i en organisatorisk udvikling hen imod en lærende organisation. Konsekvensen af at betragte TQM og den lærende organisation som rettet mod hver sin del af organisationen, sagsbehandling og medarbejdere, var imidlertid, at den lærende organisation blev fanget $\mathrm{i}$ et dilemma mellem effektivisering og læring. Det uddyber jeg i analyseafsnittet - først introduceres forskningsmetoden. 


\section{Forskningsmetoden}

Jeg fulgte det tredje ud af fire hold AC'ere før, under og efter deres kursus. Fra maj-juni 1995 lavede jeg før-interviews med deltagerne med det formål at danne mig et billede af AC'erne i Offad. Jeg var især interesseret i deres beskrivelser og vurderinger af, hvordan organisationen havde forberedt dem på den lærende organisation, samt hvordan de betragtede denne nye organisationsform og deres parathed til at deltage $\mathrm{i}$ den.

Derefter var jeg deltagende observatør på AC'ernes kursus. Det løb fra midten af august til midten af oktober 1995. Formålet med observationerne var at undersøge, hvilket indhold, der blev formidlet til AC'erne og hvilken pædagogik, der blev anvendt, samt AC'ernes reaktion herpå. I januar 1996 vendte jeg tilbage for at lave efter-interviews. Her var jeg interesseret i at få AC'erne til at beskrive og vurdere, om den lærende organisation var blevet mere synlig i Offad, og om de nu følte sig mere parate til at deltage i den nye organisation. I november 1996 afleverede jeg min rapport til Offad i form af et foredrag for alle, der ønskede at lytte.

Jeg anvendte den samme interview-guide i alle mine interviews. Et interview varede normalt mellem 30-45 minutter, hvor jeg tog noter. Dem renskrev jeg og sendte til de interviewede AC'ere for at lade dem være med-producenter af interview-teksten. Jeg tolkede materialet (også mine observations-noter) som tekster, dvs. som beskrivelser af den del af personens livsverden, der var mit fokus, og jeg anvendte en fænomenologisk metode i teksttolkningerne (Giorgi 1975, Kvale 1996). Det betød, at jeg tolkede teksten adskillige gange. I første runde var jeg mere interesseret $\mathrm{i}$ det faktiske indhold af interviewpersonens svar end $\mathrm{i}$ at passe svarene ind i et skema eller $i$ at besvare forskningsspørgsmål. Formålet var, helt i tråd med den fænomenologiske metodologi, at reducere teksterne til en mere håndterlig størrelse. I anden tolkningsrunde, der var baseret på den første, stillede jeg følgende spørgsmål til empirien: Hvad lærte AC'erne? Blev deres arbejdserfaringer inddraget i læreprocessen? Hvordan ændrede organisationen og dens arbejde sig? Førend jeg præsenterer resultatet af analysen, vil det læringsteoretiske grundlag herfor blive uddybet $\mathrm{i}$ det følgende afsnit.

\section{Organisatorisk læring og den lærende organisation}

Der har i tidens løb været gjort adskillige forsøg på at skabe overblik over forskningsfeltet om organisatorisk læring og den lærende organisation. Det er sket ved at skelne mellem et fokus på selve læreprocessen og på læreprocessens produkt eller resultat (Dodgson 1993, Elkjær 1994). Det sidstnævnte vil ofte være hægtet op på en vurdering af kvaliteten af de organisatoriske beslutninger som resultat af læreprocessen (Huber 1991, Levitt \& March 1988, Shrivastava 1983). Et overblik over litteraturen om organisatorisk læring og den lærende organisation er også blevet til ved at studere forskellige faglige discipliners behandling af forskningsfeltet, $\mathrm{fx}$ organisatorisk læring fra et psykologisk og organisationsudviklingsperspektiv versus organisatorisk læring set fra et sociologisk og organisationsteoretisk univers (Easterby-Smith 1997). Andre har hæftet sig ved, hvordan forskellige forskningsfællesskaber er opstået $i$ kølvandet af interessen for organisatorisk læring (Easterby-Smith, Snell \& Gherardi 1998). Der er også blevet skrevet om organisatorisk læring i et politisk perspektiv som et spørgsmål om 
demokratisk inddragelse af medarbejdere frem for at trække et færdigt organisatorisk design ned over hovedet på dem (Elkjær \& Lysgaard 1998, Hvenegaard \& Trolle 1996). Endelig har der været anlagt et læringsteoretisk perspektiv på forskningsfeltet (Cook \& Yanow 1993, Elkjaer 1999, Østerlund 1996). Det er det sidstnævnte, der er udgangspunktet i denne artikel.

Relationen mellem organisatorisk læring og den lærende organisation findes, men hvor organisatorisk læring først og fremmest har interesseret forskere, der er optaget af organisationsændringer af den ene eller den anden art, så er litteraturen om den lærende organisation skrevet direkte til praktiserende ledere (Argyris \& Schön 1996, c. 1978, EasterbySmith op. cit.). Det er karakteristisk for litteraturen om den lærende organisation, at udviklingen af en lærende organisation ofte tillægges overordentlig stor betydning for virksomhedens overlevelse (Pedler \& Aspinwall 1998, Senge 1990, van Hauen, Strandgaard \& Kastberg 1995). Der hersker her ingen tvivl om, at endemålet, den lærende organisation - omend ofte beskrevet i abstrakte og generelle termer - er idealet. Den lærende organisation betragtes i litteraturen herom som den bedste ramme for at udvikle medarbejdernes engagement og læring.

Når man betragter organisatorisk læring og den lærende organisation med et læringsteoretisk blik kan man skelne mellem at betragte læring ud fra et kognitivt eller et socialt-kulturelt perspektiv (Cook \& Yanow op. cit., Elkjaer 1999, Østerlund op. cit.). ${ }^{1}$ Inden for det førstnævnte perspektiv lægges vægten på læring som et epistemologisk projekt, hvor læring er lig med videnstilegnelse. En kognitivt inspireret læringsteori fokuserer på læring som overførsel af viden fra ekspert (lærer) til novice (elev). Viden anskues som en afgrænset enhed ("a body of knowledge"), der kan lagres i hjerner, bøger og computere. Den pædagogiske metode består i at inddele viden i passende doser og præsentere den for målgruppen. I den kognitivt inspirerede læringsteori arbejder man normalt med, at vidensoverførsel og -tilegnelse kan adskilles fra vidensanvendelse $\mathrm{i}$ rum (skole versus arbejde) og tid (forskellige tids- og livsfaser). ${ }^{2}$

Validiteten af den kognitivt inspirerede læringsteori er i de senere år blevet anfægtet fra flere sider. Det gælder specielt den kognitive læringsteoris mangelfulde løsning af "transferproblemet", dvs. at det er muligt at overføre viden fra bog eller person til person og fra sted til sted (Detterman \& Sternberg 1993, Salomon 1993). Det er baggrunden for at tale om læring som "situeret" (Lave \& Wenger 1991). Det betyder, at læring er relateret til den kontekst, hvori den finder sted, og at den ikke uproblematisk - eller "ucensureret" - kan overføres fra ét sted til ét andet eller fra person til person. ${ }^{3}$ Diskussionen om læreprocessens situering har ikke i så høj grad vundet indpas i teorier om organisatorisk læring og den lærende organisation - omend der er undtagelser (Brown \& Duguid 1991, Gherardi, Nicolini \& Odella 1998, Wenger 1998). Den kognitive læringsteori passer imidlertid fint med at udvikle en lærende organisation ved at lade medarbejdere deltage $i$ et kursus. Her kan deltagerne introduceres til den viden, andre har bestemt skal overføres til dem, så de kan kvalificere sig til at arbejde i en lærende organisation. Derved kommer den lærende organisation mere til at handle om at ændre individer end om at ændre de organisatoriske rammer for læreprocesserne.

Når man anlægger et socialt-kulturelt perspektiv på læring, er læring på én og samme tid en socialiseringsproces samt en udviklings- og læreproces. Viden bliver til gennem løsning af de problemfyldte situationer, der møder én i arbejdet og i hverdagslivet. Det betyder, at læring opstår i relationen mellem individets (og gruppens) interaktion med et praksisfelt (der godt kan 
være forsøget på at forstå en teori) og det sociale rum, der favner denne relation (som ikke nødvendigvis er et konkret og fysisk rum, men godt kan være et rum skabt i fantasien eller $\mathrm{i}$ forestillingen).

Et socialt-kulturelt perspektiv på læring præsenterer ikke sig selv som en fuldt og færdig teori, som man kan læse i en bog. I stedet har jeg sammensat den ved at lytte til de problemer, det giver at arbejde ud fra et kognitivt perspektiv på læring (Bamberger 1991, Lave 1988, Miller 1995, Orr 1996, Schön 1983, 1987, Sfard 1998, Østerlund op. cit.). Udgangspunktet er, at der overføres andet end viden i læreprocessen, og at det i øvrigt er tvivlsomt, om viden er en afgrænset "størrelse". Kritikken går også på, om mennesker lærer noget, de kan anvende fx i en arbejdssituation ved at få præsenteret viden i en skole- og kursussammenhæng. Det sidstnævnte handler om den før nævnte transferproblematik. Forsøg på at forstå, hvad og hvordan mennesker lærer, er imidlertid langt fra noget nyt. Det forsøgte den amerikanske pragmatiske filosof og uddannelsestænker, John Dewey (1859-1952), allerede for over 100 år siden. Dewey's teorier om læring og viden kan på mange måder kaste et forklarelsens lys på nyere forsøg på at definere læring som et socialt-kulturelt fænomen (Dewey 1916, c. 1966, 1933, 1938, c. 1963, 1938). Det er baggrunden for at inddrage Dewey's begreber i den følgende problematisering af grundpillerne i et kognitivt syn på læring.

Læring som vidensoverførsel fra ekspert til novice blev allerede for en del år siden problematiseret med introduktionen af begrebet "den skjulte læreplan" (Bauer \& Borg 1976, c. 1986, Broady 1981). Den skjulte læreplan er alt dét, der overføres sammen med den åbne læreplan gennem de institutionelle rammer for uddannelse og den kulturelle arv, den repræsenterer. Denne medlæring, der er en følge af den skjulte læreplan, kan kaldes læreprocessens socialisering (Rasmussen 1999). Den skjulte læreplan kan også rummes i Bourdieu's (1990) begreb, "praksislogik" (the logic of practice). Det betyder, at aktører (fx lærere og elever) handler inden for en given praksislogik og i overensstemmelse med deres relationer til denne praksis. Problematiseringen af læring som vidensoverførsel betyder, at når en lærende organisation udvikles gennem kursusvirksomhed, så følger det levede liv i organisationen og organisationens arbejdspraksis med over i kurset som en skjult læreplan. Det er med organisationen som baggrund, at kursisterne vurderer kursusforløb og -indhold.

Viden som en veldefineret størrelse, der let kan opbevares i diverse "beholdere" - herunder hjernen - er blevet udfordret af hele den post-moderne æra og den social-konstruktivistiske bevægelse i dens mange varianter (se fx Berger \& Luckmann 1990, c. 1966). Dewey afviste imidlertid helt begrebet viden og foreslog termen "berettigede udsagn" (eng.: warranted assertibilities) for at indikere, at viden både er kontekstuel og kontinuerlig (Dewey 1938, 7ff). Dewey opponerede imod forestillingen om, at viden kan udvikles gennem abstrakte propositioner således som formallogikken foreskriver. I stedet hævdede han, at viden altid skabes gennem udforskning (eng.: inquiry) $\mathrm{i}-\mathrm{og}$ af - problematiske situationer.

Dewey beskriver udforskning som en proces, der begynder med en fornemmelse af, at et eller andet er galt. Man kan intuitivt ane, at der er et problem. Denne fornemmelse opstår ikke nødvendigvis på baggrund af et intellektuelt vid. Først i det øjeblik udforsker(ne) begynder at definere og formulere problemet, bevæger udforskningen sig ind $\mathrm{i}$ et intellektuelt felt ved, at der gøres brug af den menneskelige evne til at ræsonnere og tænke. Udforsker(ne) gør med andre ord 
brug af deres hidtidige erfaringer med lignende situationer. Derefter vil udforsker(ne), ifølge Dewey, forsøge at løse problemet ved at prøve sig frem ("trial and error") og afslutte med at teste en løsningsmodel. For at problemet skal være løst, må den indledende fornemmelse af usikkerhed - den usikkerhed, der førte til, at udforskningsprocessen gik i gang, imidlertid være forsvundet. For at udforskning skal resultere i nye erfaringer, må tænkningen eller refleksionen over relationen mellem problemets definition og formulering samt løsningen heraf imidlertid i spil. Det er først, når relationen mellem handlingen og handlingens konsekvens(er) etableres via refleksionen, at læring har fundet sted.

Når viden bliver til via udforskning af de konkrete problemer, man møder på sin vej, og når løsningen af problemet afhænger af, at man er i stand til både at handle (for at løse problemet) og at tænke (for at forstå relationen mellem problemets formulering og dets løsning), så bliver det afgørende at inddrage de erfaringer, deltagerne møder op med på fx et kursus. Erfaringer er dog ikke det samme som oplevelser, og læringserfaringer adskiller sig fra de erfaringer, der socialiserer os til fx at arbejde i en bestemt virksomhed. Jeg beskriver i det følgende Dewey's erfaringsbegreb, fordi det kan anvendes til at præcisere forskellen mellem læring og socialisering. ${ }^{4}$

Resultatet af udforskninger af problematiske situationer er, at vi gør os nogle nye erfaringer. Vi konstruerer med andre ord nye "berettigede udsagn" - eller "viden" for nu at forblive i den velkendte terminologi. Den viden, vi kan skabe, afhænger dels af vores evne til at reflektere over relationen mellem vore handlinger og de konsekvenser, de afføder, dels afhænger det af de relationer, vi er i stand til at etablere til de erfaringer, vi tidligere har gjort os. Der er dog forskel på at gøre sig erfaringer og "bare" at opleve noget.

"Det er ikke erfaring, når et barn blot stikker sin finger ind i en flamme; det er først erfaring, når bevægelsen forbindes med den smerte, som barnet oplever som en konsekvens heraf. Det medfører, at det at stikke en finger ind i en flamme for altid fremover vil betyde en smerte. At brænde sig er blot en fysisk ændring, der minder om at brænde et stykke træ, hvis det ikke erkendes som en konsekvens af en handling."

(Dewey 1916, c. 1966, 139-140, hans understregning, min oversættelse).

Det er gennem en opmærksomhed på betydningen af vores omgang med verden, at vi kan skabe erfaringer. Der er imidlertid også forskel på at gøre sig erfaringer og at gøre sig læringserfaringer - eller såkaldte "refleksive" erfaringer. ${ }^{5}$ Vi gør os erfaringer som et resultat af, hvordan vi lever vores liv, og hvordan vi omgås andre mennesker. Det er igen afhængigt af, hvem vi er som personer, og hvordan vi indgår i disse relationer, men det er svært at undgå at gøre sig erfaringer. Men hvis vi skal lære af de erfaringer, vi gør os, er vi nødt til at anvende vore evner til ikke blot at tænke på relationen mellem vore handlinger og deres konsekvenser, men også at relatere dem til vore nuværende erfaringer. Først da bliver erfaringer til refleksive erfaringer - til læringserfaringer.

Differentieringen i erfaringsbegrebet kan rummes inden for forskellen mellem socialisering og læring. Det betyder naturligvis ikke, at man nødvendigvis kan - eller skal - adskille socialisering og læring. Det er to sider af samme sag. Men det betyder, at læringserfaringer ikke bare er noget, 
man "gives". Læringserfaringer kræver en aktiv indsats i form af refleksion og tænkning samt at hidtidige erfaringer kan bringes i spil med de erfaringer, man kontinuerligt gør sig. Det er forudsætningen for, at man kan "bruge" sine gjorte erfaringer til at handle stadigt mere informeret i de nye problematiske situationer, man møder på sin vej. ${ }^{6}$ Skellet mellem erfaringer og læringserfaringer understreger nødvendigheden af at arbejde med deltagernes erfaringer i fx Offad's kursus for AC'erne. Det understreger tillige læring som en aktiv og intenderet proces, der går ud over socialisering. Det er iført disse læringsteoretiske briller, at jeg i det følgende besvarer spørgsmålet om, hvad AC'erne lærte på deres kursus og om AC'erne's arbejdserfaringer blev inddraget. Først er det dog nødvendigt at uddybe, hvad sagsbehandling var i Offad, fordi det rummer kimen til at forstå den dobbelthed mellem rationalisering og udvikling, der udspillede sig i Offad's bestræbelser på at blive en lærende organisation.

\section{AC'erne og arbejdets "dobbeltkarakter"}

Der var 26 AC'ere på det hold, jeg fulgte på deres kursus. De var jævnt fordelt på alle de forskellige kontorer i Offad. De fleste af dem var sagsbehandlere af enkeltsager, enkelte var generelle sagsbehandlere, mens et par af AC'erne ikke arbejdede som sagsbehandlere, men udførte andre akademiske funktioner i Offad (så som edb og oversættelse). Aldersspredningen på holdet var stor, omend hovedparten var unge. For mange var det deres første job som jurist, og halvdelen af dem havde kun arbejdet i Offad i et år eller mindre. Denne holdsammensætning svarede i øvrigt til sammensætningen af AC'ere i hele Offad.

Sagsbehandling af enkeltsager fulgte en bestemt rutine i Offad samtidig med, at det blev udført af højtuddannede akademikere, idet det krævede en uddannelse som jurist eller tilsvarende for at blive ansat som juridisk sagsbehandler. Rutiniseringen af arbejdet betød, at sagsbehandling af enkeltsager kunne minde om industriel masseproduktion. Arbejdet kunne nemt måles og tælles, og det kvantitative aspekt af sagsbehandling var da også meget tydelig i Offad. Det gjaldt lige fra distributionen af sager til organisationens ansigt udadtil. Det sidstnævnte blev publiceret $\mathrm{i}$ Offad's Årsberetning, der var fyldt med tal. I Årsberetningen kunne man fx læse, at der havde været en konstant forøgelse af sager, og at "produktionsstatistikken" havde været for opadgående i en årrække.

Antallet af sager var ligeledes meget synlig, når man trådte ind på kontoret hos en sagsbehandler af enkeltsager. Han eller hun havde bunker af sager liggende på borde og reoler. Retorikken omkring sagsbehandling af enkeltsager reflekterede arbejdets kvantitative karakter, idet sagsbehandlere af enkeltsager beskrev deres arbejde som "akkordarbejde". Kontorerne for enkeltsager blev desuden betegnet som Offad's "produktion".

På trods af denne sprogbrug lånt fra industrien lagde AC'erne dog også meget vægt på det kvalitative aspekt ved behandlingen af enkeltsager. AC'erne beskrev deres arbejde som "fagligt udfordrende" pga. dets kombination af juridiske, sociale og andre fagligheder. En anden kvalitet ved arbejdet var værdien og nødvendigheden af det. Sagsbehandling i Offad var nødvendig, så længe mennesker havde brug for den form for økonomisk støtte, Offad ydede. Så selvom det var muligt at referere til arbejdet som "masseproduktion", var det en produktion, der involverede menneskeskæbner. Hver sag handlede om et medmenneskes liv, som AC'erne følte sig ansvarlige for fik den økonomiske kompensation, de ifølge loven havde krav på. 
Det var denne dobbelthed i karakteren af AC'ernes arbejde med sagsbehandling, der banede vejen for at tænke indførelsen af de to organisatoriske omstillinger, TQM og den lærende organisation, som to sider af samme sag. På den ene side kunne arbejdet beskrives i kvantitative og målbare termer og håndteres i et rationaliseringsprojekt (TQM). På den anden side havde det også karakter af at være højt kvalificeret arbejde, der var fagligt udfordrende. Det var det kvalitative aspekt ved arbejdet, der lå til grund for at udvikle en lærende organisation i Offad. Det var baggrunden for at tænke i udvikling af medarbejdere som det væsentligste element $\mathrm{i}$ udviklingen af en lærende organisation.

Det er muligt at spore arbejdets “dobbeltkarakter” i kursets vidensoverførsel til AC'erne, eftersom den både reflekterede en kvalitativ, udviklingsorienteret og en kvantitativ, målbar stemme. Stemmerne havde imidlertid ikke samme styrke - faktisk var den sidstnævnte temmelig stille i kursets udtalte budskaber og begrundelser for at udvikle en lærende organisation.

\section{Det dobbelte budskab til AC'erne}

Det udtalte budskab til AC'erne var, at organisationen ønskede at gøre bedre brug af deres færdigheder og viden ved at sende dem på et kursus. Formålet med dette var at forberede AC'erne til at påtage sig mere generelle opgaver i den lærende organisation. Offad's ledelse ønskede, at AC'erne i en lærende organisation skulle påtage sig et større ansvar for udviklingen af organisationen. AC'erne skulle fx påtage sig et ansvar for en succesfyldt indførelse af TQM projektet, den lærende organisation og omstillingen af kontorpersonalet til sagsbehandlere. "Det er oplagt, at ledelsen ønsker at gøre os til mere motiverede, mere samarbejdende og glade medarbejdere, som så til gengæld vil bidrage til at forbedre kvaliteten af arbejdet i Offad", sagde én AC'er i mine før-interviews.

Det tavse - eller mere tyste - budskab var mere forvirrende og modsætningsfyldt end det udtalte, men det kan læses ud af den måde, hvorpå den lærende organisation skulle materialisere sig nemlig ved at kræve, at alle AC'ere uanset arbejdspraksis skulle deltage i det samme kursus. Indholdet i kurset var det samme for alle, selvom det primært var designet til at omstille sagsbehandlere af enkeltsager til at påtage sig de mere generelle opgaver. "Har alle virkelig det samme behov for uddannelse?”, spurgte én af de generelle sagsbehandlere i mine før-interviews.

Derudover medførte den tidspressede organisering af kurset et stort pres på AC’erne. Næsten alle var positive over for at deltage i uddannelse, men tidspresset mindskede glæden. De fleste af AC'erne havde desuden det samme antal sager, mens de deltog i kurset, hvilket yderligere bidrog til at skabe stress omkring kurset. "Skal man virkelig ofre så meget for at blive en lærende organisation?", var en undren hos en generel sagsbehandler i mine efter-interviews.

Organiseringen af kurset på denne stressende måde bidrog til at overføre den forståelse, AC'erne havde af sig selv som en "stor, grå masseproducerende gruppe". Kurset bidrog ikke éntydigt til at sende $\mathrm{AC}$ 'erne et andet signal på trods af den megen læggen vægt på udvikling og læring i det åbne og udviklingsorienterede budskab på kurset. Det betød, at AC'erne havde svært ved at se sig selv som fuldgyldige og ansvarlige medspillere i Offad's udvikling hen imod en lærende organisation. 
Budskabet til AC'erne var tvetydigt, eftersom organiseringen af kurset overførte et andet budskab end det udtalte og udviklingsorienterede i selve kursets indhold. Der var med andre ord et skjult og modsatrettet - budskab, der blev overført sammen med det åbne. Det var en refleksion af arbejdets dobbelte karakter og den form for lærende organisation, man indførte i Offad. Her blev arbejdets rationalisering tænkt ind i et kvantitativt og målbart projekt, TQM, mens udviklingen af den lærende organisation blev tænkt som en udvikling af medarbejdernes holdninger og adfærd til arbejdets rationalisering. Den viden, som AC'erne tilegnede sig i omstillingsprojektet, reflekterede dette dobbelte budskab.

\section{Mere social samhørighed og effektivitetstænkning}

AC'ernes hold var sammensat på tværs af kontorer, hvilket betød, at AC'erne lærte kollegaer fra andre kontorer at kende. Det skabte efterfølgende en større social samhørighed og en følelse af at være en del af en fælles kultur. AC'erne beskrev, hvorledes omstillingskurset havde betydet en "forbedret korpsånd" og en "større følelse af solidaritet i hele huset". Kurset resulterede også i bedre relationer til ledelsen og især til kontorcheferne, som tidligere havde været temmelig usynlige. Det skyldtes især ledelsens tilstedeværelse på det afsluttende seminar.

En del af AC'ernes videnstilegnelse igennem omstillingsprojektets organisering var således, at social samhørighed og gensidig synlighed var positivt ladede værdier i Offad. En anden side af videnstilegnelsen var en konsekvens af den måde den arbejdsmæssige praksis blev integreret eller rettere sagt ikke integreret i kurset. For eksempel var undervisningen i principperne om TQM én lang gruppearbejdsproces, som varede 1 hel dag og noget af en aften. Resultatet var, at ingen tilegnede sig egentlige færdigheder $\mathrm{i}$ at håndtere metoderne i TQM konceptet. Undervisningen formåede blot at give AC'erne en idé om, hvad indførelsen af TQM i Offad betød for sagsbehandlingen. Men det havde sin effekt, idet AC'erne efterfølgende tænkte mere i effektivitet, når de udførte sagsbehandling. Det betød, at AC'erne tænkte i TQM tal, når de skulle foretage sagsafgørelser: "Hvis jeg anerkender eller afviser dette som en sag, hvilken indflydelse vil det så have for den efterfølgende sagsbehandling og tidsfaktoren (dvs. på kvalitetstallene)?” Kravet om en større effektivitet efterlod sit mærke på AC'ernes holdninger til deres arbejdspraksis - og til den måde, hvorpå de udførte sagsbehandlingen.

Det var viden om den positive værdi af social sammenhæng og effektivitet, AC'erne tilegnede sig gennem deres kursus og dets organisering. Det var imidlertid ikke en viden hos AC'erne om, at de som mere eller mindre erfarne sagsbehandlere kunne - eller skulle - deltage i udviklingen af sagsbehandlingen. Det var lagt $\mathrm{i}$ hænderne på konsulenterne og blev håndteret $\mathrm{i}$ TQM projektet, der var rettet mod at rationalisere arbejdsprocessen. Denne grænse mellem de to områder organisationens arbejdspraksis og medarbejdernes læring og udvikling - blev yderligere forstærket ved ikke at involvere AC'ernes arbejdserfaringer med sagsbehandling. AC'ernes erfaringer fremstod ganske enkelt ikke som nødvendige for at udvikle en lærende organisation i Offad.

\section{De unødvendige arbejdserfaringer}

Bortset fra modulet om "Total kvalitet og personlig kvalitet", der konkret tog udgangspunkt i TQM projektet i Offad, var der ingen reel forbindelse til Offad som en organisation - eller som en offentlig virksomhed. Modulerne, "Præsentations- og forhandlingsteknik" samt "Skriftlig 
kommunikation", var begge ideelt set rettet mod at træne nyttige færdigheder. Men eksemplerne, der blev anvendt i forstnævnte modul relaterede sig ikke til AC'ernes erfaringer i Offad.

Angående det sidstnævnte modul, så stillede AC'erne spørgsmål ved, om det var muligt at skrive sagsafgørelser i et andet og mere læsevenligt sprog: "Vil kontorchefen ikke blot ville stoppe denne sprogbrug ved at referere til nødvendigheden af at anvende det traditionelle juridiske fagsprog i breve til klienter?”, spurgte sagsbehandlerne på kurset.

Denne manglende relation til det daglige arbejde betød også en mangel på muligheder for i fællesskab at diskutere og lære af de forbehold, AC'erne havde mod forandringerne af deres arbejdspraksis i Offad. For eksempel blev den tvivl, som mange af AC'erne havde om konsekvenserne for deres arbejde af TQM projektet, ikke diskuteret i fællesskab. Denne tvivl blev afsløret over for mig i mine interviews med AC'erne og gennem mere uformelle samtaler under observationerne. Fx sagde en sagsbehandler i et efter-interview: "Jeg synes, at kvalitet lig med tid er noget ævl." Konsekvenserne af at tale om kvalitet, når det mest handlede om kvantitet, fik AC'erne til at protestere: "Er kvalitet lig med større produktivitet og effektivitet?"; "Hvad sker der med den fagligt kvalificerede og retfærdige sagsbehandling?", spurgte sagsbehandlere i efter-interviewene. Nogle af AC'erne var ligefrem begyndt at tvivle på, om god sagsbehandling stadig blev betragtet som et vigtigt kriterium for at arbejde i Offad. "Er sagsbehandling blevet et nødvendigt onde i Offad?", spurgte en AC'er i mine efter-interviews.

Projektarbejdet var den eneste forbindelse til hverdagens arbejdsliv i Offad. Projektarbejdet forløb imidlertid som en parallel aktivitet til kurset og blev udført under det samme tidspres som resten af omstillingskurset. Derudover blev projektarbejdet taget meget alvorligt af AC'erne, og en hel del mere arbejde end de anviste 4,5 dage blev lagt i projekterne. Nogle af projekterne blev fulgt op ved at nedsætte permanente og ad hoc arbejdsgrupper for at fortsætte arbejdet her. Ved at gøre det kom arbejdsgrupperne til at være en slags forbindelse mellem omstillingskurset og den lærende organisation. Projektarbejdet og arbejdsgrupperne var dermed en måde at gøre bedre kvalitativ brug af AC'ernes erfaringer.

Der var imidlertid meget stress omkring projektarbejdet, fordi ledelsen skulle kommentere på de færdige projekter på afslutningseminaret. Derved fik præsentationerne karakter af at være eksamenssituationer. Det var ligeledes ledelsens vurdering af projekterne, der afgjorde, om AC'erne skulle videreføre arbejdet i arbejdsgrupper. Fx fortæller en AC'er i mine efterinterviews, at projektgruppen ikke har været samlet efter projektfremlæggelsen og at "motivationen for at arbejde videre ned projektet heller ikke var så stor, fordi kontorchefen fra $\mathrm{X}$-kontor var uenig med gruppens konklusion. Den faldt vist ikke i så god jord." Det betød, at projektarbejdet ikke kan betragtes som en mulighed for at inddrage AC'ernes erfaringer i forsøget på at skabe en lærende organisation i Offad. Projektarbejdet blev mere en socialisering til, hvor grænserne var for AC'ernes virke i Offad.

Overførslen af AC'ernes videnstilegnelse fra det uddannelsesmæssige rum til arbejdsorganisationen blev yderligere forhindret af, at arbejdet i det organisatoriske rum ikke forandrede sig under indførelsen af den lærende organisation. Fx siger en AC'er i et efterinterview: "Jeg er glad for mit arbejde, men jeg laver stadig sager, der hverken er værre eller bedre end før." Derimod ændrede de organisatoriske strukturer sig, så AC'erne oplevede at blive udsat for mere kontrol i løbet af den fase, hvor de deltog i kurser. Oplevelsen af mere kontrol 
forstærkede fornemmelsen af, at arbejdsorganisationen og rummet for uddannelse repræsenterede to modsatrettede logikker.

\section{De to læringsrum}

Uddannelsesrummet efterlod AC'erne med en fornemmelse af ændring og udvikling. De skulle påtage sig rollen som "ledere" af kontorpersonalets omstillingsprojekt, og de skulle være "ansvarlige" udviklere af organisationen - især for den lærende organisations succesfyldte indførelse. Det skabte nye forventninger til at arbejde i Offad. Det betød, at når fx en gruppe løst ansatte medarbejdere ikke blev genansat, så rystede det organisationens medarbejdere mere, end hvis organisationen ikke havde kaldt sig "lærende". "I en lærende organisation er der nogle forventninger om mere demokrati, og det er meget vanskeligere at modtage en ordre", sagde en AC'er i mine efter-interviews.

Indførelsen af den lærende organisation i Offad ændrede imidlertid ikke de organisatoriske strukturer i nævneværdig grad. Kontorerne (læs: kontorcheferne) fortsatte deres indbyrdes rivalisering om allokeringen af ressourcer og spændende opgaver. Og på trods af budskabet om, at AC'erne skulle være "ledere" af omstillingen af kontorpersonalet, så var kontorcheferne stadig ledere af både kontorpersonalet og AC'erne. 'Der er skabt mudder i kompetencen. På den ene side udviskes nogle formelle magtstrukturer, fordi vi skal være så lige, lære af hinanden osv. Men der er stadig hierarkier både uformelt indbyrdes og formelt", fortæller en AC'er i mine efterinterviews.

Denne mangel på ændringer i det organisatoriske hierarki bidrog til oplevelsen af tvetydighed blandt AC'erne om formålet med at udvikle en lærende organisation i Offad. Tvetydigheden blev yderligere forstærket af indførelsen af mere kontrol i Offad ved at introducere et stempelur og præstationsbaseret aflønning. Det var som om følgende ambivalente holdning til at udvikle en lærende organisation i Offad lå til grund for hele projektet: "Vi vil gerne bruge jeres akademiske kompetencer noget mere til at løse de mange nye opgaver, som vi forventer at skulle løse i Offad, men på samme tid vil vi også gerne udøve en større ledelseskontrol med jeres arbejde og tidsforbrug." Det får en AC'er til at udtale følgende i mine efter-interviews: "På mange måder er Offad blevet en bedre arbejdsplads. Men på den negative front er der også sket noget, fx er der kommet meget mere kontrol med vores arbejde. Man kan næsten tale om 'Big Brother' tilstande. Det virker på mig som i modstrid med skabelsen af en lærende organisation. Kontrollen handler om den øgede edb-kontrol. Det virker som en mistillid til medarbejderne. Og det er faktisk unødvendigt, fordi folks arbejdsmoral er rimelig høj. Den store vægt på kvalitetsmåling er jo også kontrol."

Her illustreres dobbeltheden i udviklingen af den lærende organisation i forlængelse af et TQM projekt. Ændringer af strukturer og arbejdspraksis fandt sted langs en kvantitativ og let målbar logik i TQM projektet, mens det var ændring og udvikling af medarbejdere, der skulle bære den lærende organisation igennem. Vi ser her den kognitive læringsteori for fuld udblæsning med dens påstand om, at viden kan overføres fra uddannelsesstedet til anvendelsesstedet uden hensyn til de to rums forskellige logikker. Det var troen på, at viden kunne overføres til AC'erne på et kursus ved at fortælle dem om deres nye og mere ansvarlige rolle i en lærende organisation. De historiske individuelle og kollektive erfaringer fra arbejdsorganisationen og fraværet af ændringer i de organisatoriske strukturer, blev ikke betragtet som væsentlige elementer i udviklingen af den lærende organisation i Offad. 


\section{Konklusion}

Jeg indledte artiklen med at påpege ledelsens fremsynethed og medarbejdernes interesse $\mathrm{i}$ at bidrage til at udvikle Offad til en lærende organisation. Det giver heller ingen mening at lægge skylden på projektets udfald på konsulenternes skuldre. Det handler ikke om at udpege helte og skurke, når man skal vurdere udfaldet af et organisationsudviklingsprojekt som den lærende organisation i Offad. Der er heller ikke noget grundlæggende forkert i at rationalisere og effektivisere nogle arbejdsprocesser, der ikke er hensigtsmæssige. Sagsbehandlingen i Offad havde netop - også - karakter af at være rutiniseret arbejde, hvor rutinerne kunne gøres til genstand for et TQM projekt.

“Anklagen" mod projektets udfald, der viser sig ved, at Offad ikke i dag er kendt som en lærende organisation, skal rettes mod den grundlæggende dobbelthed, der omgav hele projektet, og som afspejler organisationens arbejdsmæssige praksis. Det vil sige troen på, at en lærende organisation kan udvikles gennem kursusvirksomhed, hvor indholdet er bestemt af andre, og hvor formålet er at udvikle og ændre på medarbejdere. Dette skete samtidig med gennemførelsen af et andet projekt (TQM), hvis formål var at rationalisere sagsbehandlingen i organisationen - alt imens kontrollen med medarbejdernes arbejde blev forstærket i organisationen. Det anvendte kognitive perspektiv på læring rummer ingen relation mellem medarbejderes erfaringsudvikling og udviklingen af eksempelvis sagsbehandling gennem udforskning.

Man kan dog ikke reducere udfaldet af forsøget på at skabe en lærende organisation i Offad til at være udelukkende et spørgsmål om at følge en bestemt læringsteori. Karakteren af arbejdet i Offad indeholdt en grundlæggende dobbelthed, der repræsenterede denne dobbelte appel til henholdsvis et TQM rationaliseringsprojekt og en lærende organisation med et udviklingsorienteret syn på medarbejdere. Arbejdet i Offad havde både karakter af industriel masseproduktion og blev udført af højt uddannede medarbejdere. Det var denne modsatrettede dobbelthed, der viste sig i det dobbelte budskab til AC'erne i Offad. Kursets indhold signalerede læring og udvikling, mens kursets afvikling mest mindede om masseuddannelse. Udbyttet for AC'erne afspejlede dobbeltheden, idet de både oplevede en større social samhørighed oven på kurset og samtidig i højere grad arbejdede med effektivitet i sagsbehandlingen for øje.

Dobbeltheden viste sig også i relation til inddragelsen af AC'ernes arbejdserfaringer, hvor det på den ene side ikke var muligt åbent at diskutere eventuelle forbehold over for udviklingen af den lærende organisation og indførelsen af TQM. På den anden side var projektarbejdet et sted, hvor det var muligt for AC'erne at udfolde sine arbejdsmæssige erfaringer. Projektarbejdet kom dog qua dets karakter af eksamen i højere grad til at fungere som en socialisation til, hvad man kunne og hvad man ikke kunne sige og gøre i Offad, end det blev elementer i AC'ernes lærings- og udviklingsproces. Dobbeltheden i Offad's projekt om at indføre en lærende organisation viste sig dog allermest $\mathrm{i}$ de to læringsrums to forskellige logikker. For det første var der det uddannelsesmæssige rum, der var præget af læring og udvikling, og for det andet var der det organisatoriske rum, der var præget af inerti kombineret med gennemførelsen af mere kontrol. 
Inspirationen fra en social-kulturel læringsteori ville have krævet, at den situerede karakter af den organisatoriske læreproces var blevet taget alvorligt ved at satse på at udvikle organisationen til at rumme ét eller flere rum for udforskning - problemformulering, "trial and error", problemløsning og refleksion. Det kunne relativt nemt være sket i Offad ved fx at inddrage tutorarrangementet som gensidige læreprocesser frem for at lægge vægten på, at AC'erne skulle være "ledere" og ansvarlige for kontorpersonalets kompetenceudvikling. Det ville dog have krævet, at de organisatoriske strukturer ikke var blevet friholdt for ændringer. I Offad ændrede organisationen sig kun lidt, men til gengæld pegede disse strukturelle ændringer i en modsat retning end den lærende organisation.

Projektet om udviklingen af en lærende organisation i Offad viser, at udviklingen af en lærende organisation - eller organisatorisk læring - ikke kun kan ske som et

medarbejderudviklingsprojekt. Troen på, at den lærende organisation kan udvikles ved at overføre den "rigtige" viden til medarbejdere gennem kursusvirksomhed og så forvente, at den efterfølgende videnstilegnelse for alvor vil rykke hele organisationen - når de organisatoriske kontrolstrukturer tilmed skærpes - har sine rødder i en kognitiv læringsteori. Denne teori - og praksis - er yderst vedholdende, men fremmer ikke organisatoriske læreprocesser. Den fremmer allerhøjest en socialisering til at arbejde i en organisation, hvori der skal arbejdes mere effektivt. 


\section{Litteratur}

Anderson, John R., Reder, Lynne M. \& Simon, Herbert A. (1996): Situated Learning and Education, i Educational Researcher 25(4), 5-11.

Anderson, John R., Reder, Lynne M. \& Simon, Herbert A. (1997): Situative Versus Cognitive Perspectives: Form Versus Substance, i Educational Researcher 26(1), 18-21.

Argyris, Chris \& Schön, Donald A. (1996, c. 1978): Organizational Learning II. Theory, Method, and Practice, Reading, Addison-Wesley Publishing Company.

Bamberger, Jeanne (1991): The Mind Behind the Musical Ear, Cambridge, Harvard University Press.

Bauer, Mette \& Borg, Karin (1976, s. 1986): Den skjulte lcereplan, København, Unge Pædagoger.

Berger, Peter L. \& Luckmann, Thomas (1990, c. 1966): Den samfundsskabte virkelighed. En videnssociologisk afhandling, København, Lindhardt \& Ringhof.

Bourdieu, Pierre (1990): The Logic of Practice, Cambridge, Polity Press.

Broady, Donald (1981): Den dolda Lärorplan, Stockholm.

Brown, John S. \& Duguid, Paul (1991): Organizational Learning and Communities-of-Practice: Toward a Unified View of Working, Learning, and Innovation, i Organization Science, 2(1), 4057.

Brown, John S., Collins, Allan \& Duguid, Paul (1989a): Situated Cognition and the Culture of Learning, i Educational Researcher 18(1), 32-42.

Brown, John S., Collins, Allan \& Duguid, Paul (1989b): Debating the Situation. A rejoinder to Palincsar and Wineburg, i Educational Researcher 18(4), 10-12.

Cook, Scott D. N. \& Yanow, Dvora (1993): Culture and Organizational Learning, i Journal of Management Inquiry, 2(4), 373-390.

Detterman, Douglas K. \& Sternberg, Robert J. (eds.) (1993): Transfer on Trial: Intelligence, Cognition, and Instruction, Norwood, Ablex Publishing Corporation.

Dewey, John (1905, c. 1981): The Postulate of Immediate Empiricism, i J. J. McDermott (ed.) The Philosophy of John Dewey. The Structure of Experience (Vol. 1); The Lived Experience (Vol. 2), Chicago and London, The University of Chicago Press. 
Dewey, John (1916, c. 1966): Democracy and Education. An Introduction to the Philosophy of Education, New York, The Free Press.

Dewey, John (1933): How We Think: A Restatement of the Relation of Reflective Thinking to the Educative Process, Boston, D. C. Heath and Company.

Dewey, John (1938): Logic. The Theory of Inquiry, New York, Henry Holt and Company.

Dewey, John (1938, c. 1963): Experience and Education, New York, Collier Books. Dodgson, Mark (1993): Organisational Learning: A Review of Some Literatures, i Organization Studies 14(3), 375-394.

Easterby-Smith, Mark (1997): Disciplines of Organizational Learning: Contributions and Critiques, i Human Relations 50(9), 1085-1113.

Easterby-Smith, Mark, Snell, Robin \& Gherardi, Silvia (1998): Organizational Learning: Diverging Communities of Practice?, i Management Learning 29(3), 259-272.

Elkjaer, Bente (1999): In search of a social learning theory, i M. Easterby-Smith, L. Araujo \& J. Burgoyne (eds.) Organizational Learning and the Learning Organisation. Developments in Theory and Practice, London, Sage.

Elkjær, Bente \& Lysgaard, Anne-Grete (1998): Med loereprocessens blik. En undersøgelse af konsulentprojekter i mindre virksomheder, København, Samfundslitteratur.

Elkjær, Bente (1994), Arbejde som kontinuerlig læreproces?, i LOKE. Om arbejdsmiljø, teknologi, samfund, uddannelse 12, 3-5.

Gherardi, Silvia, Nicolini, Davide \& Odella, Francesca (1998): Toward a Social Understanding of How People Learn in Organizations. The Notion of Situated Curriculum, i Management Learning 29(3): 273-297.

Giorgi, Amadeo (1975): An Application of Phenomenological Method in Psychology, i A. Giorgi, C. Fischer \& E. Murray (eds.) Duquesne Studies in Phenomenological Psychology, II, Pittsburgh, Duquesne University.

Greeno, James G. (1997): On Claims That Answer the Wrong Questions, i Educational Researcher 26(1), 5-17.

Huber, George P. (1991): Organizational Learning: the contributing processes and the literatures, i Organization Science 2(1): 88-115.

Hvenegaard, Hans \& Trolle, Herluf(1996): Den laerende organisation. Fra udbraendthed til udvikling, København, Arbejdsmiljøfondet. 
Kvale, Steinar (1996): InterViews. An introduction to qualitative research interviewing, Thousand Oaks, Sage.

Lave, Jean \& Wenger, Etienne (1991): Situated Learning. Legitimate Peripheral Participation, Cambridge, Cambridge University Press.

Lave, Jean (1988): Cognition in Practice. Mind, Mathematics and Culture in Everyday Life, Cambridge, Cambridge University Press.

Levitt, Barbara \& March, James G. (1988): Organizational Learning, i Annual Review of Sociology 14, 319-340.

Miller, Crispin M. (1995): So can you build one? Learning through designing - connecting theory with hardware in engineering education, Massachusetts, Massachusetts Institute of Technology, Dept. of Mechanical Engineering.

Orr, Julian E. (1996): Talking about machines. An ethnography of a modern job, Ithaca, ILR Press.

Palincsar, Annemarie S. (1989): Less Charted Waters, i Educational Researcher 18(4), 5-7. Pedler, Mike \& Aspinwall, Kath (1998): A Concise Guide to the Learning Organization, London, Lemos\&Crane.

Philips, D. C. (1995): The Good, the Bad, and the Ugly: The Many Faces of Constructivism, i Educational Researcher, 24(7), 5-12.

Piaget, Jean (1973): Psykologi og erkendelse. København, Hans Reitzel.

Prawat, Richard S. (1995): Misreading Dewey: Reform, Projects, and the Language Game, i Educational Researcher, 24(7), 13-22.

Rasmussen, Jens (1999): Mesterlære og den almene pædagogik, i K. Nielsen \& S. Kvale (eds.) Mesterlcere. Laering som social praksis, København, Hans Reitzels Forlag.

Salomon, Gavriel (ed.) (1993): Distributed Cognitions. Psychological and educational considerations, Cambridge, Cambridge University Press.

Schön, Donald A. (1983): The Reflective Practitioner. How Professionals Think in Action, New York, Basic Books.

Schön, Donald A. (1987): Educating the reflective practitioner: toward a new design for teaching and learning in the professions, New York, Basic Books.

Senge, Peter M. (1990): The Fifth Discipline. The Art \& Practice of the Learning Organization, New York, Doubleday Currency. 
Sfard, Anna (1998): On Two Metaphors for Learning and the Dangers of Choosing Just One, i Educational Researcher (27)2: 4-13.

Shrivastava, Paul (1983): A Typology of Organizational Learning Systems, i Journal of Management Studies 20(1), 7-28.

van Hauen, Finn, Strandgaard, Vagn \& Kastberg, Bjarne (1995): Den loerende organisation - om evnen til at skabe kollektiv forandring, København, Industriens Forlag.

Wenger, Etienne (1998): Communities of Practice. Learning, Meaning, and Identity, Cambridge, Cambridge University Press.

Wineburg, Samuel S. (1989), Remembrance of Theories Past, i Educational Researcher 18(4), 7 10 .

Østerlund, Carsten S. (1996): Learning Across Contexts. A field study of salespeople's learning at work, i Psykologisk Skriftserie (21)1, Aarhus, Aarhus Universitet.

\section{Noter}

${ }^{1}$ Jeg har i denne gennemgang ikke nævnt "klassikeren” om organisatorisk læring, Argyris \& Schön (1996, c. 1978).

Årsagen er, at Argyris \& Schön’s perspektiv på organisatorisk læring er en blanding af et organisationsudviklingsperspektiv, hvor man kan hævde, at de har et kognitivt syn på læring qua deres begreb om “mentale modeller", eller omvendt påstå at de har et socialt-kulturelt syn på læring, fordi de selv betegner deres teori som et "handlingsteoretisk" bud på en teori om organisatorisk læring, og at de i øvrigt i deres læringsteoretiske modeller trækker på Dewey (se senere).

${ }^{2}$ Karakteristikken af et kognitivt perspektiv på læring er ud over de nævnte forfattere inspireret af Jean Lave’s arbejde med at definere læring ud fra en antropologisk teori og metode (Lave 1988, 1997). Et kognitivt perspektiv på læring har sin oprindelse i udvikling af læringsteorier på et individualt-psykologisk grundlag, hvor begrebet livsfaser (barndom, ungdom, voksenalder) og udviklingstrin er af afgørende betydning for læreprocessens forløb og udfald. Piaget (1973) er en væsentlig bidragsyder til et kognitivt perspektiv på læring, omend dette - også - kan gøres til genstand for diskussion, se fx Philips 1995, Prawat 1995.

${ }^{3}$ Se også diskussionen mellem på den ene side Brown, Collins \& Duguid (1989a, 1989b) og på den anden side Palincsar (1989) og Wineburg (1989). Den senere diskussion mellem Anderson, Reder \& Simon (1996, 1997) og Greeno (1996) er ligeledes interessant for belysning af spørgsmålet om transfer versus "situated” læring.

${ }^{4}$ Når der i denne artikel lægges så meget vægt på deltagernes erfaringer, så er der måske en og anden, der gerne ville spørge mig, om det er er genopliven af den såkaldte "erfaringspædagogik" (for en udmærket opsummering af denne tradition inden for uddannelsesforskningen, se Christensen, Frederiksen \& Roth 1985). Dertil vil jeg svare, at der er 
den betydelige forskel på den kritiske teori's erfaringsbegreb, således som den repræsenteres i

“erfaringspædagogikken” og Dewey's erfaringsbegreb, at Dewey afviser referencen til "grand theories" (først og fremmest marxismen), som foruden psykoanalysen er en af grundpillerne i “erfaringspædagogikken”. Dewey anser ganske enkelt teorier, som er så abstraherede fra det levede hverdagsliv, som han anså marxismen for at være, for ikke at have nogen forklaringsværdi for mennesker i deres forsøg på at forstå verden. Denne holdning forhindrede dog ikke Dewey i at blive anklaget for at være socialist og venstreorienteret - eller det, der er værre! Det forhindrer heller ikke nutidige Dewey-forskere for at kalde sig demokratiske "venstresocialister", der dog ikke helt kan sammenlignes med vort hjemlige VS.

${ }^{5}$ Dewey udviklede sit begreb om erfaring igennem hele sit liv, og det er ikke helt klart, hvordan han definerede begrebet. For interesserede læsere, så har jeg især anvendt hans 1905 (c. 1981) essay, ”The Postulate of Immediate Empericism" og hans hovedværk om uddannelse (1916, c. 1966) for at spore forskellene i hans begreb om erfaring.

${ }^{6}$ Dewey ville vende sig adskillige gange i sin grav på Burlington kirkegård, hvis han læste noget, der bare kunne give associationer om, at man overhovedet kan gøre sig erfaringer uden at tænke. For erfaringer gøres netop ved at etablere relationen mellem handlinger og konsekvenser ved hjælp af tænkningen. Men jeg betragter forskellen mellem erfaringer og læringserfaringer som gradsforskelle mellem i hvor høj grad, man kan etablere forbindelser til sine tidligere erfaringer, eller om erfaringer udelukkende er bundet til situationen. Forudsætningen for at lære, for at "vokse" og udvikle sig er netop, at man kan lave denne forbindelse til sine tidligere erfaringer.

Bente Elkjær, Lektor ved Institut for Informatik, Handelshøjskolen i København, e-mail: be.inf@cbs.dk 